\title{
Early introduction of complementary food and childhood stunting were linked among children aged 6-23 months
}

\author{
Bunga Astria Paramashanti ${ }^{1,2}$, Stella Benita ${ }^{2}$ \\ ${ }^{1}$ Department of Nutrition, Faculty of Health Sciences, Universitas Alma Ata, Yogyakarta, Indonesia \\ ${ }^{2}$ Sydney School of Public Health, The University of Sydney, NSW 2006, Australia
}

\begin{abstract}
Background: Indonesia's national stunting prevalence remains high. The transition from exclusive breastfeeding to poor complementary feeding practices may put infants at higher risk of becoming stunting. Objective: This study aimed to analyse the relationship between the early introduction of complementary food and stunting among young children aged 6-23 months in Kebumen Regency. Methods: A cross-sectional study design was conducted among 307 young children in Kebumen Regency, Central Java Province, Indonesia, by using multistage cluster sampling. Our primary outcome was stunting or height-for-age z-score $<-2$, whereas independent variables were child, maternal, and household factors. Univariate and multivariate logistic regression were performed to assess significant determinants at the level of significance 0.05. Results: Timely introduction of complementary food was a protective factor against stunting (AOR=0.54; 95\%CI: 0.31-0.94). Female children were less likely to be associated with stunting ( $A O R=0.54 ; 95 \%$ CI: 0.32-0.93). Conversely, variables which significantly increased the risk of becoming stunting included older children aged 12-17 months (AOR $=2.01 ; 95 \% C I: 1.05-3.84)$ and $18-23$ months $(A O R=4.17 ; 95 \% C I: 2.15-8.08)$ and maternal occupation in agricultural sectors (AOR=3.77; 95\%CI: 1.17-12.1). Conclusions: Child factors associated with stunting was the first timing of complementary feeding, child sex, and child age. Maternal factor linked to stunting was mother's occupation in the agricultural sector. This study indicated that child and maternal factors play essential roles in childhood stunting.
\end{abstract}

KEYWORDS: factors associated; infants and young children; stunting; timing of complementary food introduction

\section{INTRODUCTION}

Growth failure is commonly found in children under five years old. In Indonesia, the stunting rate remains high, even though there is an improvement in the overall economy (1). National Institute of Health and Research Development 2018 reported a very high rate of stunting with $30.8 \%$ of children were stunted (2). Hence, increasing understanding of stunting's determinants for specific settings is of high importance to reduce its magnitude and impacts.

As soon as delivery, the mean of length-for-age Z-score is already placed below the reference and drops considerably until the children reach two years of age (3). While stunting may begin since $u t e r o$, it indicates that there are vital roles of maternal factors such as poor nutrition before and during pregnancy, short maternal stature, teenage pregnancy, infections, short birth interval, and poor mental health (4). At the child level, repeated infections and poor breastfeeding practices such as delayed initiation, not exclusively breastfed, and early weaning breastfeeding may contribute to stunted growth (4). Meanwhile, a much greater problem was seen between six and 24 months during the complementary feeding period $(3,4)$. This period highlights the significance of breastmilk transition to foods with issues such as inadequate energy content of food, poor dietary diversity, low micronutrients, infrequent feeding, and poor hygiene practice when handling foods (4).

Corresponding author: Bunga Astria Paramashanti, Department of Nutrition, Faculty of Health Sciences, Universitas Alma Ata, Jalan Brawijaya No. 99 Tamantirto, Bantul, Yogyakarta, 55183, Indonesia, Tel: +62 274434 2288, Fax: +62 274434 2269, e-mail: bunga@almaata.ac.id

How to cite: Paramashanti BA, Benita S. Early introduction of complementary food and childhood stunting were linked among children aged 6-23 months. Jurnal Gizi Klinik Indonesia. 2020;17(1):1-8. doi: 10.22146/ijen.53788 
Stunting may occur from multi-faceted factors. Household and community factors also play an important part in childhood stunting. At the household level, issues include food insecurity, poor sanitation and water supply, inadequate child care and stimulation, and low educational attainment of caregivers (4). In a broader context, community factors that may influence are health care systems, education, culture, food system, environment, political economy, urbanization, and social supports $(4,5)$.

In Indonesia, several studies have been conducted to assess the determinants of stunted growth among children. A multilevel analysis of Basic Health Research showed that associated factors of stunting were history of low birth weight, male sex, older age children, parity more than three, less than four antenatal care visits, and higher household wealth (6). Using similar data, another study provided almost alike results adding that exclusive breastfeeding was not one of the significant factors (7). The relationship between exclusive breastfeeding and stunting indeed gave inconsistent results across studies in Indonesia (8-11). Inappropriate feeding practices which were linked to stunting also included timing of first complementary food $(12,13)$ indicating that there might be a nutritional inadequacy or unsafety food handling (14). However, these studies were limited by smaller sample size, limited geographical area, and did not accommodate multivariate analysis to control the confounding variables.

The World Health Organization (WHO) global nutrition target for stunting is to reach $40 \%$ reduction of total stunted children (15). Currently, Indonesia is working ambitiously through the National Strategy to Accelerate Stunting Prevention 2017-2021 that aims to reduce the stunting rates by using an evidence-driven approach, better resources utilisation and better coordination across levels (16). Such efforts should involve multi-sectoral coordination with national, regional, and community levels (1). Kebumen Regency in Central Java is one of the 100 cities/districts prioritised by Indonesians government because of its high proportions of stunting (33.8\%) as well as poverty (19.9\%) (16). Based on Indonesia's current stunting condition and due to the limitation of risk factor studies in Central Java, this study aimed to analyse the association between early introduction of complementary food and stunting among 6-23 months children in Kebumen Regency.

\section{METHODS}

\section{Study design and participants}

This study involved a secondary analysis of available datasets obtaining from the survey conducted in 2018 in Kebumen Subdistrict, Kebumen Regency, Central Java Province. The survey was aimed to assess the dietary intakes of infant and young children. Young child-mother pairs were selected by using multistage cluster sampling. Firstly, two villages were chosen in each of the three primary health centres in Kebumen Subdistrict. Secondly, all children who were aged 6-23 months and joined posyandu (integrated health post) at the village level when the survey was conducted were included. After the study samples reached the minimum quota of the sample size, which was 356 , the recruitment processed was stopped. For the purpose of this analysis, we excluded children with incomplete data either in stunting status or dietary practices. Previously, all mothers signed informed consent before the interview was conducted. Ethical clearance of this study was obtained from Research Ethics Committee of Universitas Alma Ata (No: $\mathrm{KE} / \mathrm{AA} / \mathrm{IV} / 510 / \mathrm{EC} / 2018$ ).

Posyand $u$ is a community-based health effort carried out by, from, and to the community in order to empower and provide facilities for the community to obtain health services for mothers, infants, and children under the age of five years old. The main activities cover maternal and child health, family planning, immunization, nutrition, and infection prevention and management (17). Generally, nutrition programs within posyandu included growth monitoring, nutrition counselling or education, and supplementary feeding.

\section{Measures}

Our dependent variable was stunting. The independent variables were classified into three main categories which include child, parental, and household factors. Child factors were age, sex, the timing of first complementary food, and intake of energy and protein. Parental factors were age, education, and occupation. All the data were obtained by locally trained nutritionists with a minimum of a 3 -year graduate nutrition diploma.

Stunting. Child body length was measured using a portable length board. Length-for-age Z-score (LAZ) 
was estimated using the WHO 2006 growth standard (18). Children with LAZ below minus two standard deviations $(<-2)$ from the median of reference population were considered stunted.

The timing of first complementary food. The timing of complementary food introduction followed the WHO and The United Nations International Children's Fund (UNICEF) recommendations to be timely. It is when the exclusive breastfeeding for the first six months cannot meet the energy and nutrients needs (19). Furthermore, we divided complementary feeding timing into early $(<6$ months) and timely ( $\geq 6$ months) (12).

Intake of energy and protein. Energy and protein intakes of young children were obtained using 24-hour recall to mothers. Both energy and protein intakes were categorized as adequate $(\geq 80 \%$ of Indonesia's Recommended Daily Intake (RDI)) and inadequate ( $<80 \%$ of RDI) (20).

Education. Maternal and paternal education consists of primary school, junior high school, senior high school, and higher degree. We described any mother and father who ever joined a certain level of education were considered as having that certain educational attainment as we did not consider whether they finished or not finished these educational levels. Further, we classified a high educational level when mothers or fathers completed or once ever enrolled at least senior high school.

Occupation. Parental occupation was divided as not working, working in agricultural or non-agricultural fields. Agricultural fields covered crops, livestock, fisheries, and forests (21).

Household factor. The household factor was household monthly income with minimum regional wage as the cut-off. In 2018, Kebumen's minimum regional wage was 1,558,793 IDR.

\section{Data analysis}

Our analysis began with basic descriptive statistics presenting the proportion of child and family characteristics and the distribution of stunting status and child feeding practices. We conducted univariate logistic regression to estimate the strength of association of each explanatory variable and childhood stunting, whereas multiple logistic regression was performed to examine the strength of the relationship of study variables together at the same time. The level of significance was 0.05. All of the analyses were done using Stata 14.2.

\section{RESULTS}

Table 1 presents the characteristics of young child-mother pairs. A total of 307 children aged 6-23 months were enrolled in the 2018 survey. The majority of children were aged 6-11 months and females. Most of their mothers and fathers aged above 30 years old and

Table 1. Characteristics of young children aged 6-23 months

\begin{tabular}{|c|c|c|}
\hline Characteristics & $\mathbf{n}$ & $\%$ \\
\hline \multicolumn{3}{|l|}{ Child's age (months) } \\
\hline $6-11$ & 123 & 40.0 \\
\hline $12-17$ & 100 & 32.6 \\
\hline $18-23$ & 84 & 27.4 \\
\hline \multicolumn{3}{|l|}{ Child's sex } \\
\hline Male & 122 & 39.7 \\
\hline Female & 185 & 60.3 \\
\hline \multicolumn{3}{|l|}{ Mother's age (years) } \\
\hline$<30$ & 140 & 45.6 \\
\hline$\geq 30$ & 167 & 54.4 \\
\hline \multicolumn{3}{|l|}{ Mother's education } \\
\hline Primary school & 76 & 24.8 \\
\hline Junior high school & 100 & 32.6 \\
\hline Senior high school & 110 & 35.8 \\
\hline Higher education & 21 & 6.8 \\
\hline \multicolumn{3}{|l|}{ Mother's occupation } \\
\hline Not working & 233 & 75.9 \\
\hline Agricultural sectors & 14 & 4.6 \\
\hline Non-agricultural sectors & 60 & 19.5 \\
\hline \multicolumn{3}{|l|}{ Father's age (years) } \\
\hline$<30$ & 55 & 18.0 \\
\hline$\geq 30$ & 251 & 82.0 \\
\hline \multicolumn{3}{|l|}{ Father's education } \\
\hline Primary school & 73 & 23.8 \\
\hline Junior high school & 61 & 19.9 \\
\hline Senior high school & 144 & 46.9 \\
\hline Higher education & 29 & 9.4 \\
\hline \multicolumn{3}{|l|}{ Father's occupation } \\
\hline Agricultural sectors & 134 & 43.7 \\
\hline Non-agricultural sectors & 173 & 56.4 \\
\hline \multicolumn{3}{|l|}{ Household income* } \\
\hline$<$ minimum wage & 157 & 51.1 \\
\hline$\geq$ minimum wage & 150 & 48.9 \\
\hline
\end{tabular}

*Kebumen's minimum regional wage $=1,558,793$ IDR 
Table 2. Distribution of childhood stunting and dietary practices

\begin{tabular}{lrr}
\hline Main variables & $\mathbf{n}$ & $\mathbf{\%}$ \\
\hline Stunting & & \\
$\quad$ No & 220 & 71.7 \\
$\quad$ Yes & 87 & 28.3 \\
Timing of complementary food introduction & & \\
$\quad$ Early ( $<6$ months) & 127 & 41.4 \\
$\quad$ Timely ( $\geq 6$ months) & 180 & 58.6 \\
Energy intake & & \\
$\quad$ Inadequate & 84 & 27.4 \\
$\quad$ Adequate & 223 & 72.6 \\
Protein intake & & \\
$\quad$ Inadequate & 42 & 13.7 \\
$\quad$ Adequate & 265 & 86.3 \\
\hline
\end{tabular}

completed secondary schools. Around half of the children coming from poor households.

Stunting and dietary-related distribution of the children in the study are shown in Table 2. Almost a third $(28.3 \%)$ of the children were stunted. A large proportion of children had timely initiation of complementary feeding $(58.6 \%)$, adequate energy and protein intake (72.6\% and $86.3 \%$, respectively).

Table 3 presents factors associated with stunting in children aged 6-23 months. In bivariate analysis, age of children and maternal occupation in the agricultural field were the only variables that significantly associated with stunting. Age of mothers, maternal education, age of fathers, paternal education, paternal occupation, energy intake, and protein intake were not significantly related to childhood stunting. However, we kept all variables which had a $p$-value $<0.25$ for multiple logistic regression analysis, thus sex of children $(p=0.097)$ and timing of complementary feeding $(\mathrm{p}=0.125)$ were also included.

After controlling for other predictors in the multivariate analysis, our results showed that young children aged 12-17 months (adjusted $\mathrm{OR}=2.01$; 95\% $\mathrm{CI}$ : 1.05-3.84) and 18-23 months (adjusted $\mathrm{OR}=4.17$; 95\% $\%$ : 2.15-8.08) were positively associated with stunting. Being female was protective against childhood stunting two times lower (95\% CI: 0.32-0.93) compared to male children. Maternal work in agricultural sectors had 3.77 times higher chance to have stunted children $(95 \% \mathrm{CI}$ : 1.17-12.1) than mothers who did not have any job. There was no difference in the strength of association between maternal work in the non-agricultural field and those who were housewives in term of having a stunted child (adjusted OR=0.83; 95\%CI: 0.42-1.63) (Table 3).

\section{DISCUSSION}

Prevalence of stunting in this study was $28.3 \%$. Based on the results of a further analysis of Indonesia's national data, the proportion was below the national proportion of stunting prevalence among children aged 6-23, which was $34.7 \%$ (7). However, based on de Onis et al (22), the proportion is considered as high, which is between 20 and $29.9 \%$. The National Strategy to Accelerate Stunting Prevention is one of the key programs to eradicate stunting in Indonesia from national to local government-level which focuses on food security, mother-child care practices, sanitation, and health system (1). In 2017, the government of Indonesia, under the National Team for the Acceleration of Poverty Reduction, has launched joint recommendations to control stunting by maximizing stunting-related program coordination and implementation in 100 cities/districts, including in Kebumen Regency $(16,23)$. Such efforts are still far from the target. In the Medium-Term Development Plan (RPJMN) 2015-2019, Indonesia's government set the target to decrease stunting to $28 \%$ in 2019 (1); however, current stunting rate remained high. Overall, there is a need to transform stunting prevention policies into lowerlevel implementation in the field, including to implement, to monitor, and to evaluate comprehensive collaboration between sectors in order to achieve stunting eradication goal in national and local settings.

Early introduction of complementary feeding was associated with childhood stunting. Young children who were given their first food before they reached six months of age were more likely to become stunted two times higher than children who consumed complementary food at six months. Previous studies conducted among young children confirmed our Kebumen's study $(12,24)$. For infants, breast milk provides the best nutritional source and improves the development of the immune system. Early weaning of breastfeeding would cause impairment in the immunologic controls against 
Table 3. Bivariate and multivariate results of stunting determinants among young children aged 6-23 months in Kebumen Regency

\begin{tabular}{|c|c|c|c|c|c|c|}
\hline \multirow{2}{*}{ Variables } & \multicolumn{3}{|c|}{ Bivariate } & \multicolumn{3}{|c|}{ Multivariate } \\
\hline & COR & $95 \%$ CI & $\mathbf{p}$ & AOR & $95 \% \mathrm{CI}$ & $\mathbf{p}$ \\
\hline \multicolumn{7}{|l|}{ Child's age (months) } \\
\hline $6-11$ & Ref & & & Ref & & \\
\hline $12-17$ & 1.88 & $0.99-3.53$ & 0.051 & 2.01 & $1.05-3.84$ & 0.036 \\
\hline $18-23$ & 3.44 & $1.83-6.48$ & $<0.0001$ & 4.17 & $2.15-8.08$ & $<0.0001$ \\
\hline \multicolumn{7}{|l|}{ Child's sex } \\
\hline Male & Ref & & & Ref & & \\
\hline Female & 0.65 & $0.40-1.08$ & 0.097 & 0.54 & $0.32-0.93$ & 0.027 \\
\hline \multicolumn{7}{|l|}{ Mother's age (years) } \\
\hline$<30$ & Ref & & & & & \\
\hline$\geq 30$ & 1.04 & $0.63-1.72$ & 0.864 & & & \\
\hline \multicolumn{7}{|l|}{ Mother's education } \\
\hline Low & Ref & & & & & \\
\hline High & 0.93 & $0.56-1.54$ & 0.774 & & & \\
\hline \multicolumn{7}{|l|}{ Mother's occupation } \\
\hline Not working & Ref & & & Ref & & \\
\hline Agricultural sectors & 3.60 & $1.20-10.8$ & 0.022 & 3.77 & $1.17-12.1$ & 0.026 \\
\hline Non-agricultural sectors & 0.98 & $0.52-1.86$ & 0.954 & 0.83 & $0.42-1.63$ & 0.584 \\
\hline \multicolumn{7}{|l|}{ Father's age (years) } \\
\hline$<30$ & Ref & & & & & \\
\hline$\geq 30$ & 0.96 & $0.51-1.83$ & 0.905 & & & \\
\hline \multicolumn{7}{|l|}{ Father's education } \\
\hline Low & Ref & & & & & \\
\hline High & 0.94 & $0.57-1.54$ & 0.793 & & & \\
\hline \multicolumn{7}{|l|}{ Father's occupation } \\
\hline Agricultural sectors & Ref & & & & & \\
\hline Non-agricultural sectors & 1.14 & $0.69-1.88$ & 0.614 & & & \\
\hline \multicolumn{7}{|l|}{ Household income* } \\
\hline$<$ minimum wage & Ref & & & & & \\
\hline$\geq$ minimum wage & 1.10 & $0.67-1.81$ & 0.715 & & & \\
\hline \multicolumn{7}{|c|}{ Timing of complementary food introduction } \\
\hline Early (<6 months) & Ref & & & Ref & & \\
\hline Timely (at 6 months) & 0.67 & $0.40-1.12$ & 0.125 & 0.54 & $0.31-0.94$ & 0.029 \\
\hline \multicolumn{7}{|l|}{ Energy intake } \\
\hline Inadequate & Ref & & & & & \\
\hline Adequate & 0.98 & $0.56-1.72$ & 0.956 & & & \\
\hline \multicolumn{7}{|l|}{ Protein intake } \\
\hline Inadequate & Ref & & & & & \\
\hline Adequate & 0.99 & $0.48-2.03$ & 0.971 & & & \\
\hline
\end{tabular}

$\mathrm{COR}=$ crude odds ratio; $\mathrm{AOR}=$ adjusted odds ratio; $\mathrm{p}=\mathrm{p}$-value; $*$ Kebumen's minimum regional wage $=1,558,793 \mathrm{IDR}$

hypersensitivity reactions and autoimmune illnesses (25). When the infants were given breastmilk substitute before six months, they would be placed at risk of bacterial contamination, especially in poor settings where water was contaminated and mothers were not able to prepare any replacement feeding properly such as unsterilized bottle, not boiling the water, no clean cooking and eating cutlery, and no refrigerator for food storage. Breastmilk, on the other hand, is remarkably safe (26). An earlier study showed that exclusive breastfeeding cessation 
before six months increased the risk of infectious illnesses such as fever (27) and diarrhea (7,27). Infection-related physiological conditions may later disrupt growth by inhibiting nutrient absorption, increasing nutrient losses, decreasing appetite, and turning nutrients away from growth, thus restricting children from achieving their growth potential (28). However, there was no data on infections gathered in this survey. This finding suggest that it is highly important to provide children with foods which are timely, nutritious, and safe (19).

We found that the risk of stunting was increased as the child got older. Young children aged 12-17 months had twice higher chance to become stunted, whereas 18-23 months old group were more likely to be stunted four times higher than those who were below 12 months. The results were confirmed by previous studies $(6,29,30)$. Although stunting could start since in utero, it may continue to postnatal life when a child reaches two years of age (31). Growth faltering may be the result of exclusive breastfeeding transition to semi-solid or solid foods provided that breastmilk is hygiene and meeting the child's age-appropriate nutrient requirements (32). Roche et al (29) stated that child's age between one and two years old put the children at a higher risk of inadequate complementary foods, especially in the first few months of complementary feeding period. As our study did not find any relationship between the energy and protein adequacy, we assumed that other dietary aspects might contribute to stunting such as micronutrients (e.g., iron, calcium, zinc) (33). More focus should be given in providing adequate infant and young child feeding in both quantity and quality, especially during the complementary feeding period.

Male children tend to be stunted compared to female children. Studies conducted in South Africa (34) and Indonesia (6) were in line with this study finding. A study among Senegalese children indicated that males were more likely to experience linear growth faltering because they were at risk of having shorter breastfeeding duration, being fed at an earlier age, or already being undernourished previously. Another possibility was the biological difference which was not related to infant feeding suggesting that boys were more vulnerable to infectious diseases compared to girls due to the increased risk of immunodeficiency (35). Nevertheless, we found an unusual proportion between males and females in this study that may affect the association between the sex of the child and stunting. We assumed that the uncommon sex distribution of samples could be due to the survey process which only covered Posyandu clusters, thus not all children in the study area participated resulting in more female children.

Young children whose mothers worked in agriculture had approximately four times higher risk to experience stunted growth compared to non-working mothers or mothers who worked in non-agriculture. Working in the agricultural sector was significantly associated with poor children's diet suggesting more time away from home and less time for cooking and childcaring. However, the effect was varied by the household wealth in which women whose families had more assets could reduce their workload and time spent on agricultural activities compared to those who had fewer household assets (36). Farm production systems could be another explanation of factors contributing to a household diet (37). In contrast, we did not find a relationship between family income and stunting. The possible explanation is because there was a homogenous distribution between the poor (51.1\%) and the rich (48.9\%) families in the study area. A longitudinal study conducted in South India that used income as the measure of household economic level revealed a similar finding (38). In term of accurate measure, the use of household income as an indicator of household economic status may raise another limitation compared to the household wealth index (39).

As with any other cross-sectional studies, this study had some limitations. The design did not let us develop a causal-effect relationship. The information in the survey was based on interviews in which some of them were retrospective information causing the possibility of recall bias. Additionally, this study lacked other potential factors such as breastfeeding and pre- and postnatal maternal nutrition. However, this was the first study in Kebumen Regency which examined childhood stunting determinants with representative sample size. We also used internationally recommended operational definition, which allows us to generalize and to compare our findings with other studies in similar settings. 


\section{CONCLUSIONS}

Being male, older in age, received complementary feeding initiated before six months of age and having mothers working in agricultural sectors are more likely to be associated with childhood stunting. The current results indicate future stunting reduction programs should be a context-specific, as in results of this study in Kebumen, to focus more on the pregnant and lactating mothers' preparedness to provide optimum complementary feeding practices. Community-based programs such as Posyandu should cover stunting-related programs to all children in their working area, both males and females, every age-group, especially those who reside and work in the agricultural area. In future studies, researchers should consider other proxy indicators of infant and young child feeding practices, such as initiation of breastfeeding, exclusive breastfeeding, minimum dietary diversity, minimum meal frequency, and minimum acceptable diet as well as maternal nutrition.

\section{Declaration of conflicting interests}

The authors declare that they have no competing interests.

\section{REFERENCES}

1. World Bank Group. Aiming high: Indonesia's ambition to reduce stunting. Washington: World Bank; 2018.

2. Laporan Nasional Riskesdas 2018. National Institute of Health and Research Development (Balitbangkes). [series online] 2019 [cited September 27 2019]. Available from: URL: http://labdata.litbang.kemkes.go.id/images/ download/laporan/RKD/2018/Laporan_Nasional_ RKD2018_FINAL.pdf

3. Victora CG, De Onis M, Hallal PC, Blössner M, Shrimpton R. Worldwide timing of growth faltering: revisiting implications for interventions. Pediatrics. 2010;125(3):e473-80. doi: 10.1542/peds.2009-1519

4. Stewart CP, Iannotti L, Dewey KG, Michaelsen KF, Onyango AW. Contextualising complementary feeding in a broader framework for stunting prevention. Matern Child Nutr. 2013;9(S2):27-45. doi: 10.1111/men.12088

5. Prendergast AJ, Humphrey JH. The stunting syndrome in developing countries. Paediatr Int Child Health. 2014;34(4):2 50-65. doi: 10.1179/2046905514Y.0000000158

6. Titaley CR, Ariawan I, Hapsari D, Muasyaroh A, Dibley MJ. Determinants of the stunting of children under two years old in Indonesia: a multilevel analysis of the 2013
Indonesia Basic Health Survey. Nutrients. 2019;11(5):1106. doi: 10.3390/nu11051106

7. Paramashanti BA, Hadi H, Gunawan IMA. Pemberian ASI eksklusif tidak berhubungan dengan stunting pada anak usia 6-23 bulan di Indonesia. Jurnal Gizi dan Dietetik Indonesia. 2015;3(3):162-74. doi: 10.21927/ ijnd.2015.3(3).162-174

8. Lestari EF, Dwihestie LK. ASI eksklusif berhubungan dengan kejadian stunting pada balita. Jurnal Ilmiah Permas. 2020;10(2):129-36.

9. Handayani S, Kapota WN, Oktavianto E. Hubungan status ASI eksklusif dengan kejadian stunting pada batita usia 24-36 bulan di Desa Watugajah, Kabupaten Gunungkidul. Jurnal Medika Respati. 2019;14(4):287-300. doi: $10.35842 / \mathrm{mr} . v 14 \mathrm{i} 4.226$

10. Dewi S, Mu'minah I. Pemberian MP-ASI tidak berhubungan dengan kejadian stunting pada anak usia 1-3 tahun di wilayah kerja Puskesmas Sumbang I Kabupaten Banyumas. Jurnal INFOKES. 2020;10(1):5-10.

11. Najamuddin N, Rahmadani R, Suriany. Faktor yang mempengaruhi kejadian stunting pada balita usia 12-59 bulan di wilayah kerja Puskesmas Campalagian. Bina Generasi: Jurnal Kesehatan. 2020;11(2):75-83. doi: 10.35907/bgjk.v11i2.152

12. Khasanah DP, Hadi H, Paramashanti BA. Waktu pemberian makanan pendamping ASI (MP-ASI) berhubungan dengan kejadian stunting anak usia 6-23 bulan di Kecamatan Sedayu. Jurnal Gizi dan Dietetik Indonesia. 2016;4(2):10511. doi: 10.21927/ijnd.2016.4(2).105-111

13. Prihutama NY, Rahmadi FA, Hardaningsih G. Pemberian makanan pendamping ASI dini sebagai faktor risiko stunting pada anak usia 2-3 tahun. Jurnal Kedokteran Diponegoro. 2018;7(2):1419-30.

14. Tessema M, Belachew T, Ersino G. Feeding patterns and stunting during early childhood in rural communities of Sidama, South Ethiopia. Pan Afr Med J. 2013;14:75. doi: 10.11604/pamj.2013.14.75.1630

15. WHO. Resolution WHA65.6. Maternal, infant and young child nutrition. Geneva: World Health Organization; 2012.

16. National Team for the Acceleration of Poverty Reduction (TNP2K). 100 priority districts/cities for child stunting intervention. Jakarta: National Team for the Acceleration of Poverty Reduction (TNP2K); 2017. Health Promotion Center. Ayo ke posyandu. Jakarta: Ministry of Health of Indonesia; 2012.

17. Health Promotion Center. Ayo ke posyandu. Jakarta: Ministry of Health of Indonesia; 2012.

18. World Health Organization. WHO Child Growth Standards: length/heightfor-age, weight-for-age, weight-for-length, weight-for-height and body mass index-for-age: methods and development. [series online] 2006 [cited September 
3 2019]. Available from: URL: https://apps.who.int/iris/ handle/10665/43413.

19. WHO/UNICEF. Global strategy for infant and young child feeding. Geneva, Switzerland: World Health Organization; 2003.

20. Kementrian Kesehatan RI. Angka kecukupan gizi yang dianjurkan bagi bangsa Indonesia. Jakarta: Kementrian Kesehatan RI; 2013.

21. FAO. Transforming food and agriculture to achieve the SDGs: 20 interconnected actions to guide decision-makers. Rome: Food and Agriculture Organization (FAO) of the United Nations; 2018.

22. de Onis M, Borghi E, Arimond M, Webb P, Croft T, Saha $\mathrm{K}$, et al. Prevalence thresholds for wasting, overweight and stunting in children under 5 years. Public Health Nutr. 2019;22(1):175-9. doi: 10.1017/S1368980018002434

23. Pelletier DL, Frongillo EA, Gervais S, Hoey L, Menon P, Ngo T, et al. Nutrition agenda setting, policy formulation and implementation: lessons from the Mainstreaming Nutrition Initiative. Health Policy Plan. 2012;27(1):19-31. doi: 10.1093/heapol/czr011

24. Paramashanti BA, Paratmanitya Y, Marsiswati. Individual dietary diversity is strongly associated with stunting in infants and young children. Jurnal Gizi Klinik Indonesia. 2017;14(1):19-26. doi: 10.22146/ijcn.15989

25. Jackson KM, Nazar AM. Breastfeeding, the immune response, and long-term health. J Am Osteopath Assoc. 2006;106(4):203-7.

26. Victora CG, Bahl R, Barros AJD, França GVA, Horton $\mathrm{S}$, Krasevec J, et al. Breastfeeding in the 21st century: epidemiology, mechanisms, and lifelong effect. Lancet. 2016;387(10017):475-90. doi: 10.1016/S01406736(15)01024-7

27. Nigatu D, Azage M, Motbainor A. Effect of exclusive breastfeeding cessation time on childhood morbidity and adverse nutritional outcomes in Ethiopia: analysis of the demographic and health surveys. PLoS One. 2019;14(10):e0223379. doi: 10.1371/journal.pone.0223379

28. Dewey KG, Mayers DR. Early child growth: how do nutrition and infection interact?. Matern Child Nutr. 2011;7(Supp 3):129-42. doi: 10.1111/j.1740-8709.2011.00357.x

29. Roche ML, Gyorkos TW, Blouin B, Marquis GS, Sarsoza J, Kuhnlein HV. Infant and young child feeding practices and stunting in two highland provinces in Ecuador. Matern Child Nutr. 2017;13(2):e12324. doi: 10.1111/mcn.12324

30. Nkurunziza S, Meessen B, Van geertruyden JP, Korachais C. Determinants of stunting and severe stunting among Burundian children aged 6-23 months: evidence from a national cross-sectional household survey, 2014. BMC Pediatrics. 2017;17:176. doi: 10.1186/s12887017-0929-2

31. de Onis M, Branca F. Childhood stunting: a global perspective. Matern Child Nutr. 2016;12(Suppl 1):1226. doi: $10.1111 / \mathrm{mcn} .12231$

32. Przyrembel H. Timing of introduction of complementary food: short- and long-term health consequences. Ann Nutr Metab. 2012;60 Suppl 2:8-20. doi: 10.1159/000336287

33. Mallard SR, Houghton LA, Filteau S, Chisenga M, Siame J, Kasonka L, et al. Micronutrient adequacy and dietary diversity exert positive and distinct effects on linear growth in urban Zambian infants. J Nutr. 2016;146(10):2093-101. doi: 10.3945/jn.116.233890

34. Slemming W, Kagura J, Saloojee H, Richter LM. Early life risk exposure and stunting in urban South African 2-year old children. J Dev Orig Health Dis. 2017;8(3):301-10. doi: 10.1017/S2040174417000034

35. Bork KA, Diallo A. Boys are more stunted than girls from early infancy to 3 years of age in rural Senegal. J Nutr. 2017;147(5):940-7. doi: 10.3945/jn.116.243246

36. Komatsu H, Malapit HJL, Theis S. Does women's time in domestic work and agriculture affect women's and children's dietary diversity? evidence from Bangladesh, Nepal, Cambodia, Ghana, and Mozambique. Food Policy. 2018;79:256-70. doi: 10.1016/j.foodpol.2018.07.002

37. Jones AD, Shrinivas A, Bezner-Kerr R. Farm production diversity is associated with greater household dietary diversity in Malawi: findings from nationally representative data. Food Policy. 2014;46:1-12. doi: 10.1016/j.foodpol.2014.02.001

38. Rehman AM, Gladstone BP, Verghese VP, Muliyil J, Jaffar S, Kang G. Chronic growth faltering amongst a birth cohort of Indian children begins prior to weaning and is highly prevalent at three years of age. Nutr J. 2009;8:44. doi: 10.1186/1475-2891-8-44

39. Rutstein SO, Johnson K. The DHS wealth index. Calverton, Maryland: ORC Macro; 2004. 